\title{
Indoor Air Pollution (Carbon Dioxide and Total Volatile Organic Compound) and Pulmonary Disorders in Junior High School Students in Depok, West Java
}

\author{
Bambang Wispriyono ${ }^{1,2}$, Elia Yulaeva ${ }^{1}$, Budi Hartono ${ }^{1,2} \&$ Satria Pratama $^{2}$ \\ ${ }^{1}$ Department of Environmental Health, Faculty of Public Health, Universitas Indonesia, Depok, Indonesia \\ ${ }^{2}$ Center for Industrial and Environmental Health Studies, Faculty of Public Health, Universitas Indonesia, \\ Indonesia \\ Correspondence: Bambang Wispriyono, Department of Environmental Health, Faculty of Public Health, \\ Universitas Indonesia, Kampus UI, Depok 16424, Indonesia. Tel: 6221-786-3479. E-mail: bwispri@ui.ac.id
}

\author{
Received: August 25, 2018 Accepted: September 25, 2019 Online Published: October 1, 2019 \\ doi:10.5539/gjhs.v11n12p45 \\ URL: https://doi.org/10.5539/gjhs.v11n12p45
}

\begin{abstract}
Good indoor air quality in the school environment is crucial for health and productivity of the students. Indoor air pollution needs to be taken into consideration, given that one can spend $90 \%$ of their time indoor. $\mathrm{CO}_{2}$ and Total VOC is an indoor pollutant that causes pulmonary disorder. This research is to investigate the relationship between exposure of $\mathrm{CO}_{2}$, concentration, total VOC and pulmonary disorder in Junior High School students. This research used cross-sectional design conducted on March - May 2018. The samples were 139 students taken by using simple random sampling. $\mathrm{CO}_{2}$ value was measured by Q-trak, Total VOC was measured by ppbRAE and the lung function value was spirometry. Indoor $\mathrm{CO}_{2}$ concentration in Junior High School of Depok is $478.70 \mathrm{ppm}$, the average total concentration $\mathrm{VOC}$ is $6.4 \times 10^{-3} \mathrm{ppm}, \% \mathrm{KVP}=72.66, \% \mathrm{VEP}_{1}=74.52$ and $\% \mathrm{VEP}_{1} / \mathrm{KVP}=93.97$ in average, and the proportion of students with pulmonary disorder is $3.6 \%$. There is no relationship found between exposure of indoor $\mathrm{CO}_{2}$ concentration and total VOC with lung disorder $\mathrm{VEP} / \mathrm{KVP}\left(\mathrm{CO}_{2}, \mathrm{p}=1.000\right.$ and total VOC $\mathrm{p}=0.374$ ) since the number of students with lung disorder is low in number while $\mathrm{CO}_{2}$ concentration and the total VOC level is below the listed threshold. This study found no evidence that exposure was related to pulmonary disorder. A healthy and clean living behavior in school environment needs to be improved and further research on other indoor air pollutant parameters and respiratory disorders or degenerative disease should be conducted with different methods.
\end{abstract}

Keywords: carbon dioxide, total volatile organic compound, pulmonary function, school

\section{Introduction}

Good indoor air quality in the school environment is crucial for health and productivity of the students. Indoor air pollution needs to be taken into consideration, given that one can spend $90 \%$ of their time indoor (Hutter et al., 2010). Indoor air pollution is a major problem for public health globally (Bruce et al., 2000). EPA research indicates that indoor contamination is $2-5$ times at risk even reaching 100 times higher than outdoor pollution. Indoor air quality is determined by the amount contamination of the pollutant from a wider spectrum, source of pollution with the specific in accordance with the place, climate, culture, local ambient air, characteristics of buildings and indoor activities (Madureira et al., 2015).

Carbon dioxide $\left(\mathrm{CO}_{2}\right)$ is one of the air borne pollutants resulting from fossil fuels combustion (coal, natural gas, oil, solid waste, trees, wood products and particular chemical reaction (EPA, 2016). The rapid development of transportation sources is responsible for the increasing $\mathrm{CO}_{2}$ emission in the air which becomes the biggest contributor to climate change and greenhouse effect (WHO, 2009). In Indonesia in 2004, the highest $\mathrm{CO}_{2}$ emissions came from energy consumption (62\%) them human respiration $(10 \%)$ (Samiaji, 2010). Indoor $\mathrm{CO}_{2}$ concentration level reflects the indoor air quality. The main source of indoor $\mathrm{CO}_{2}$ comes from human respiratory process in that room (Mahyuddin \& Awbi, 2012).

In addition, indoor air quality in schools is marked by the complexity of various pollutant materials such as Volatile Organic Compounds (VOCs), particulate matter, aldehydes, bacteria and fungi (Madureira et al., 2015). VOC is a large group of any organic compound (excluding carbon monoxide, carbon dioxide, carbonic acid, metallic cables 
or carbonates) with high vapor pressure according to its usage condition (Cicolella, 2008; EPA, 2011). Research conducted in Texas shows that motor vehicle emissions provide optimal information to schools among traffic, followed by the use of cleaning agents, polish furniture, materials used in arts and crafts activities, use of hot air, and deodorizing cookies in the urinal pots are the sources for high indoor concentrations (Raysoni et al., 2017).

Research conducted in Hungary shows that there is a significant correlation between class characteristics and indoor pollution sources in the class facing the street as $\mathrm{PM}_{10}$ and increasing $\mathrm{CO}_{2}$ levels. The classroom wall painted with water-resistant paint correlate with the increasing level of $\mathrm{PM}_{10}$, benzene, ethylbenzene, toluene, xylene, total BTEX and formaldehyde. Classroom wall renewal less than one year correlates with the increasing level of ethylbenzene, xylene and total BTEX. Moreover, cleaning the classroom in the morning correlates with the increasing level of xylene, total BTEX and formaldehyde (Csobod, Rudnai, \& Vaskovi, 2010).

Pollutants enter the human body through inhalation, ingestion and skin penetration (ATSDR, 2003). Pollutants enter the body through inhalation route is affected by physical component factors (gas, dust, pollutant size, solubility and hygroscopic values), chemical component (direct contact with tissue, acidity, and high alkalinity level can damage cilia and enzyme system) and the host factors (Budiyono, 2001). Children are especially sensitive to environmental exposure because they are developing their organ, meaning that exposure potentially causes discomfort or even poor health condition and lifetime burden of disease (Salthammer et al., 2016).

Research conducted by Panayostis in 2001 reports that students with high $\mathrm{CO}_{2}$ concentration tend to feel drowsy, lethargic, and complaining about stuffiness or stale air (Mahyuddin \& Awbi, 2012). The have respiratory symptoms such as sneezing, wheezing, rhinitis and asthma (Ferreira \& Cardoso, 2014) and a positive trend between $\mathrm{CO}_{2}$ in the room and asthma prevalence shows $4.7 \%$ (Martins et al., 2014). Research in Canada indicates that exposure to 10 types of indoor VOC is associated with reduced pulmonary function especially in the age group below 17 (Cakmak et al., 2014). The exposure of 1.4-DCB which is an element of VOC comes from the use of air fresheners, toilet deodorizers and moth balls leads to decreasing pulmonary function in the United States population (Elliott et al., 2006). Research conducted in Portugal and Malaysia proves that VOC exposure is associated with pulmonary disease in students (Supu \& Jalaludin, 2017).

Depok is one of the big cities in West Java Province which is a buffer zones of the Special Capital Region of Jakarta with a high level of air pollution similar to other major cities in Indonesia. Pollution in Depok comes from the increasing number of motor vehicles owned by Depok residents or passing vehicle in Depok streets. It is reported that number of new vehicles reaches 8,000 for each month (Samsoedin et al., 2015). The increasing activities of transportation sector in Depok will absolutely affect the public health. The effect of air pollution resulting from vehicle emissions and indoor pollution is very important for measurement, especially measurements are taken during school hours because the school environment has an important role in the health and academic achievement of students. Research on relationship between $\mathrm{CO}_{2}$ exposure and total VOC with pulmonary disorder in junior high school students in Depok has never been conducted. This research aims to determine the relationship between exposure of $\mathrm{CO}_{2}$, concentration, total VOC and pulmonary disorder in students at school. The results of this study are able to increase knowledge and can be input for the school and the Depok regional government to improve health in the school environment.

\section{Research Method}

\subsection{Sampling}

The study used cross-sectional design and conducted in at Depok, West Java Province on March until May 2018. The population in this study was all students of grade VII and VIII Junior High School at Depok. The school criteria determined by the researcher were the school was located beside the road, near bus terminal and situated in settlements. The researcher selected three schools with two schools were taken from simple random sampling and one school determined by purposive sampling. The researcher took four classes randomly from each school, but one school was taken 2 (two) classes because there was only one class per grade.

The selection of respondents was based on the class chosen as the sample that fulfilled the inclusion criteria of students that was grade VII and VIII who were 13 to 15 years old, had healthy conditions, and offered to participate in research. While the exclusion criteria were students who have the history of respiratory disorders such as asthma and bronchitis. The sampling was conducted randomly. The total sample of this study were 139 respondents from State Junior High School A 64 respondents, State Junior High School B 59 respondents and State Junior High School C 16 respondents. Prior to the data collection, the researcher explained to the respondents and the teachers whether they were willing to participate in this research. They should sign the informed consent forms and acknowledged by their parents/guardian since the respondent came from the vulnerable age group, children. This 
research has received Ethical approval and permission from the Ethics Committee at the Faculty of Public Health, University of Indonesia number; 214/UN2.F10/PPM.00.02/2018.

\section{$2.2 \mathrm{CO}_{2}$ and Total VOC Concentration Measurement}

The $\mathrm{CO}_{2}$ and total VOC measurement was conducted indoor and outdoor. The number of air sample was one point in each class (indoors) and outdoors. The measuring instruments are placed in classrooms in the middle of classrooms and in front of classrooms with a height of 0.5 - 1 meters from the floor to simulate student breathing zones. The measurement of $\mathrm{CO}_{2}$ concentration was conducted for one hour started at 07.30 until 12.30 a.m.; the total VOC concentration measurement was conducted for 30 minutes. Indoor air quality monitoring tools used were calibrated direct reading portable gas monitors. To measure $\mathrm{CO}_{2}$ concentration, TSI Q-Trak ${ }^{\mathrm{TM}}$ was used and to measure total VOC concentration, ppbRAE model PGM-7240 was used (Supu \& Jalaludin, 2017).

\subsection{Pulmonary Function Test}

Respondents pulmonary function test was conducted in the school using spirometry which was periodically calibrated. Spirometry was used to measure the volume of forced expiration in the first second/VEP ${ }_{1}$ (Forced Expiratory Vital/FEV ${ }_{1}$ ) and lung vital capacity/KVC (Forced Vital Capacity/FVC). The measurement was begin with an anthropometry test to measure the height of the students using microtoise by placing microtoise on the flat wall, removing footwear, standing flat on the wall, both feet touching to the wall and looking straight ahead. Then, students' weight was measured using a digital weight scale with $0.1 \mathrm{~kg}$ accuracy. The scale was placed on a flat floor and made sure to point the zero number. Afterwards, the students were asked to stand on the scale barefoot. Furthermore, pulmonary function tests are carried out by first entering data on age, sex, height and weight on spirometry when they are standing and taking deep breaths and then immediately breathing out.

The spirometry results are processed manually using numerical data contained in the normal pulmonary value table according to age and height of Indonesia (Mangunnegoro et al., 1992), and then the calculation will be produce of $\mathrm{VEP}_{1}$ and KVP presentation. Furthermore, the researcher categorized the results where the percentage of $\mathrm{VEP}_{1} \leq 80 \%, \mathrm{KVC} \leq 80 \%, \mathrm{VEP}_{1} / \mathrm{KVC} \leq 70 \%$ was included as pulmonary disorder.

\subsection{Data Analysis}

The Data is processed and presented using descriptive analysis in the form of percentages, averages, medians, standard deviations, maximum, minimums and analysis tests conducted by Fisher Exact test to identify the relationship between dependent, independent, and covariate variables. The relationship was considered as significant if the p-value was $<0.05$.

\section{Results}

Result of $\mathrm{CO}_{2}$ concentration measurement in the classroom in Junior High Schools of Depok City is in the average of $478.70 \mathrm{ppm}$. The lowest $\mathrm{CO}_{2}$ concentration is around $315 \mathrm{ppm}$, and the highest $\mathrm{CO}_{2}$ concentration is about 766 $\mathrm{ppm}$. The mean total of VOC in the classroom is $0.0054 \mathrm{ppm}$, with the lowest total of VOC concentration is 0.0001 $\mathrm{ppm}$ and the highest is $0.0029 \mathrm{ppm}$ (table 1). Meanwhile, the $\mathrm{CO}_{2}$ concentration outside the classroom produces approximately the same values that the lowest is about $251 \mathrm{ppm}$ and the highest is about $269 \mathrm{ppm}$. The concentration of outdoor total VOC in Junior High School 3 is 0.0001 ppm (data not shown).

The mean value of junior high school students' lung function based on $\% \mathrm{KVP}$ is $72.66 \%$, VEP $\%$ is 74.52 and ratio of $\mathrm{VEP}_{1} / \mathrm{KVP}$ is 93.97 (Table 1). The variable of lung function under study based on the criteria of $\mathrm{VEP}_{1} / \mathrm{KVP}$ then made into categorical form. Table 2 indicates that the proportion of pulmonary disorder in junior high school students in Depok is 3.6\%. The students' characteristics in this study show that the proportion of male and female students is similar of $50.4 \%$. The proportion of students with higher normal nutritional status is $69 \%$. The smoking students are $11.5 \%$; students with fewer physical activities are $53.2 \%$, classroom with poor ventilation are $59.7 \%$. 
Table 1. Distribution of $\mathrm{CO}_{2}$ Concentration and Total VOC in Classroom and Pulmonary Function Value in Junior High School Students in Depok

\begin{tabular}{|c|c|c|c|c|}
\hline \multirow{2}{*}{ Variable } & \multirow{2}{*}{ Mean } & \multirow{2}{*}{$\begin{array}{l}\text { Deviation } \\
\text { Standard }\end{array}$} & \multicolumn{2}{|c|}{ Value } \\
\hline & & & Min & Max \\
\hline $\mathrm{CO}_{2}$ Concentration & 478.70 & 127.71 & 315.00 & 766.00 \\
\hline VOC total concentration & 0.0054 & 0.0103 & 0.0001 & 0.0290 \\
\hline $\mathrm{KVP}<80 \%$ & 72.66 & 16.15 & 28.69 & 106.30 \\
\hline VEP $1<80 \%$ & 74.52 & 19.94 & 21.75 & 114.42 \\
\hline VEP $1 / K V P<70 \%$ & 93.97 & 11.66 & 23.77 & 100.00 \\
\hline
\end{tabular}

Table 2. Distribution of VEP $/$ KVP Lung Function Value and Respondent Characteristics in Junior High School Depok 2018

\begin{tabular}{|c|c|c|}
\hline Variable & $\begin{array}{l}\text { Total } \\
(n=139)\end{array}$ & $\begin{array}{c}\text { Percentage } \\
\text { (\%) }\end{array}$ \\
\hline \multicolumn{3}{|c|}{ VEP1/KVP Pulmonary Function } \\
\hline Disorder & 5 & 3.6 \\
\hline Normal & 134 & 96.4 \\
\hline \multicolumn{3}{|l|}{ Sex } \\
\hline Male & 69 & 49.6 \\
\hline Female & 70 & 50.4 \\
\hline \multicolumn{3}{|c|}{ Nutritional Status } \\
\hline Abnormal & 43 & 30.9 \\
\hline Normal & 96 & 69.1 \\
\hline \multicolumn{3}{|c|}{ Smoking Habit } \\
\hline Yes & 16 & 11.5 \\
\hline No & 123 & 88.5 \\
\hline \multicolumn{3}{|c|}{ Physical Activity } \\
\hline Poor & 74 & 53.2 \\
\hline Fair & 65 & 46.8 \\
\hline \multicolumn{3}{|l|}{ Ventilation } \\
\hline Inadequate & 83 & 59.7 \\
\hline Adequate & 56 & 40.3 \\
\hline
\end{tabular}

The results of bivariate data analysis showed that students exposed to $\mathrm{CO}_{2}$ concentrations with $>448 \mathrm{ppm}$ for $4.2 \%$ had pulmonary disorders while those exposed to $\mathrm{CO}_{2}$ concentrations with $<448 \mathrm{ppm}$ as much as $2.9 \%$ had pulmonary disorders with $\mathrm{p}$-value $=1,000$. Furthermore, students exposed to total VOC in the class were $1.6 \%$ and had pulmonary disorders while students exposed to the total VOC concentration $<0,0001 \mathrm{ppm}$ were $5.3 \%$ and had lung disorders with $\mathrm{p}$-value $=0.374$. the statistically variable $\mathrm{CO}_{2}$ and $\mathrm{VOC}$ did not have a significant relationship with pulmonary disorders (Table 3 ).

There is no significant relationship between the covariate variable under study pulmonary disorders in junior high school students. The sex variable obtains p-value of 1.000 with $\mathrm{OR}=0.667$ (95\% CI: $0.108-4.119)$, then based on nutritional status variables, it is obtained $p$-value of 0.645 . The OR value indicates that students with abnormal nutritional status will be 1.512 times higher ( $95 \%$ CI: 0.243 - 9.394) at risk of pulmonary disorders compared to those with normal nutritional status. Smoking habit obtains a p-value of 1.000 and OR $=1.042$ (95\% CI: 1.005 1.081 ), it means the students who are smoking have the same risk of pulmonary disorders with non-smoker 
students. Physical activity variable obtains a p-value $=1.000$. The OR score indicates that students with low physical activities have a risk of 1.331 (95\% CI: 0.215 - 8.223) higher to suffer from pulmonary disorders than those with sufficient activities. In the ventilation variable, it is obtained $p$-value $=0.392$ with OR value of 0.436 ( $95 \%$ CI: 0.285 - 24.062). This research also performed a multivariate analysis (data not shown).

Table 3. Analysis of Relationship between $\mathrm{CO}_{2}$, Total VOC, Covariate Variables and Pulmonary Disorder in Junior High School Students Depok

\begin{tabular}{|c|c|c|c|c|c|c|c|c|}
\hline \multirow{3}{*}{ Variable } & \multicolumn{4}{|c|}{ Pulmonary Function $\left(\mathrm{FEV}_{1} / \mathrm{FVC}\right)$} & \multirow{3}{*}{ Total } & \multirow{3}{*}{ P Value } & \multirow{3}{*}{ OR } & \multirow{3}{*}{$95 \% \mathrm{CI}$} \\
\hline & \multicolumn{2}{|c|}{ Disorder } & \multicolumn{2}{|c|}{ Normal } & & & & \\
\hline & $\mathbf{N}$ & $\%$ & $\mathbf{N}$ & $\mathbf{P}$ & & & & \\
\hline \multicolumn{9}{|l|}{$\mathrm{CO}_{2}$ Concentration } \\
\hline$>$ Median (448 ppm) & 3 & 4.2 & 68 & 95.8 & 71 & 1.000 & 1.456 & $0.236-9.994$ \\
\hline$\leq$ Median (448 ppm) & 2 & 2.9 & 66 & 97.1 & 68 & & & \\
\hline \multicolumn{9}{|c|}{ VOC total concentration } \\
\hline$>$ Median (0.0001) & 1 & 1.6 & 63 & 98.4 & 64 & 0.374 & 0.282 & $0.031-2.555$ \\
\hline$\leq \operatorname{Median}(0,0001)$ & 4 & 5.3 & 71 & 94.7 & 75 & & & \\
\hline \multicolumn{9}{|l|}{ Sex } \\
\hline Male & 2 & 2.9 & 67 & 97.1 & 69 & 1.000 & 0.667 & $0.108-4.119$ \\
\hline Female & 3 & 4.3 & 67 & 95.7 & 70 & & & \\
\hline \multicolumn{9}{|l|}{ Nutritional Status } \\
\hline Abnormal & 2 & 4.7 & 41 & 95.3 & 43 & 0.645 & 1.512 & $0243-9.394$ \\
\hline Normal & 3 & 3.1 & 93 & 96.9 & 96 & & & \\
\hline Smoking habit & & ' & & & & & & \\
\hline Smoking & 0 & 0.0 & 16 & 100 & 16 & 1.000 & 1.042 & $1.005-1.081$ \\
\hline Not smoking & 5 & 4.1 & 118 & 95.9 & 123 & & & \\
\hline \multicolumn{9}{|l|}{ Physical activity } \\
\hline Poor & 3 & 4.1 & 71 & 95.9 & 74 & 1,000 & 1.331 & $0.215-8.223$ \\
\hline Fair & 2 & 3.1 & 63 & 96.4 & 65 & & & \\
\hline \multicolumn{9}{|l|}{ Ventilation } \\
\hline Inadequate & 2 & 2.4 & 81 & 97.6 & 83 & 0.392 & 0436 & $0.285-24.062$ \\
\hline Adequate & 3 & 5.4 & 53 & 94.6 & 56 & & & \\
\hline
\end{tabular}

\section{Discussion}

Indoor $\mathrm{CO}_{2}$ concentration often increases due to the fact that human breath out $\mathrm{CO}_{2}$ (about $4 \%$ ) beside the inadequate ventilation factors. Research in Scandinavia measuring $\mathrm{CO}_{2}$ concentration for 3-5 days in the classroom, obtains $\mathrm{CO}_{2}$ concentration of $1086 \mathrm{ppm}$ due to inadequate class ventilation and also associated with lower attendance of the students (Gaihre et al., 2014).

The result of measurement of $\mathrm{CO}_{2}$ concentration in State Junior High School A is 408.25 ppm, State Junior High School B is $588.25 \mathrm{ppm}$ and State Junior High School C is $400.50 \mathrm{ppm}$. The results illustrate the average concentration of $\mathrm{CO}_{2}$ in the classrooms that are located adjacent to the highway, namely Junior High School A and Junior High School C, which are lower than Junior High School B located in the residential area. The concentration of $\mathrm{CO}_{2}$ is higher in 1 class compared to the other three classes due to lack of adequate ventilation which is only $4.49 \%$. When class measurement takes place in the closed room with minimal ventilation, then the $\mathrm{CO}_{2}$ concentration will be higher due to poor air exchange. While in Junior High School A there is a low $\mathrm{CO}_{2}$, level about $315 \mathrm{ppm}$ in 7.B classroom since during the measurement, some of the students have already left because the class is over. The concentration of $\mathrm{CO}_{2}$ in the classroom depends on several factors, such as the number and 
activity of the students, class density, duration of spending time in the class and the amount of fresh air entering the room. In addition, the size, number, opening position and types of the window affect the $\mathrm{CO}_{2}$ contained in the classroom which has natural ventilation (Talarosha, 2016).

In this study, the average of $\mathrm{CO}_{2}$ concentration in the classrooms in Depok Junior High School is around 478.70 ppm and above the threshold refers to the Minister of Health Regulation on Indoor Air Sanitation Number 1077 of 2010 , where the maximum limit of $\mathrm{CO}_{2}$ inside the room is $1.000 \mathrm{ppm}$. This study is in line with research conducted in elementary schools in Medan for three days that the average $\mathrm{CO}_{2}$ concentration in the class ranged from 596.5 ppm - $644.5 \mathrm{ppm}$ below the registered ASHRAE threshold (Talarosha, 2016). The same research conducted in Malaysia in three schools indicates that the measurement of $\mathrm{CO}_{2}$ concentration in the class is below the threshold of 502 ppm (Razali et al., 2015).

The observation in three schools indicates that out of the 10 classes, there is inadequate ventilation area, they are three classrooms in Junior High School A, two classrooms in Junior High School B and one classroom in Junior High School C. Referring to Regulation of Minister of Health of Republic of Indonesia Number 1429 of 2006 on School Environmental Health Requirements, the classroom ventilation area is $20 \%$. Therefore, an environmental health program intervention should be conducted through the activity of healthy school program, where the environmental health officers in Community Health Center (Puskesmas) and Depok Health Office promote and conduct environmental health inspections. Result of school environmental health inspection can be utilized as a framework of integrated cross-sector planning materials involving Provincial Development Planning Agency (BAPEDA) and Education Office (Dinas Pendidikan).

Besides $\mathrm{CO}_{2}$ pollutants, exposure to volatile organic compound has been a concern of Indoor Environment Quality (IEQ) in the schools and other buildings. VOC in the school environment shows lower level in a large room and good ventilation classroom with low occupancy ratio (Marzocca et al., 2017).

The total average of VOC concentration in Junior High School A is 0.0135 ppm, in Junior High School B is 0.0001 ppm while VOC values in Junior High School C is assumed to be the same as results in Junior High School B taking into account the characteristics and activities of students in school middle class. The difference in total VOC concentration in junior high school are activity of clean classroom by sweeping and mopping using a cleaning agent during measurement. The total concentration of VOC in Junior High School B is lower due to the low source of VOC in the classroom and the students are having the exam during the research. VOC sources in the classroom come from household products use including solvent, adhesive, paint, cleaning product, furniture and air freshener (Shook-Sa, Chen, \& Zhou, 2017). This is similar to research conducted in Texas that VOC concentrations came from cleaning agents, furniture polish, materials used in arts and crafts activities, use of hot water, and deodorizing cakes used in urinal pots were the main sources for indoor concentration high (Greenwald et al., 2013; Raysoni et al., 2017).

The research conducted in five schools in Italy involving two schools are located in petrochemical industry area. The rest are located in controlled areas away from industrial sites, indicates that VOC concentration is higher in industrial areas $\left(114.4 \pm 61.3 \mu \mathrm{g} / \mathrm{m}^{3}\right)$ compared with the concentration of VOC in the controlled areas $(80.7 \pm 33.4$ $\left.\mu \mathrm{g} / \mathrm{m}^{3}\right)$ and this difference indicates a significant relationship $(\mathrm{P}$ value $=0.004)$ (Cipolla et al., 2016). Research in United States shows that industrial areas have the highest concentration of VOC compared to suburbs and urban and the VOC concentration increases in winter (Jia, Batterman, \& Godwin, 2008). Research in India indicates that BTEX has higher significant concentration during the winter than during the spring and summer (Gaur, Singh, \& Shukla, 2016).

In this study, the average of indoor total VOC concentration in Depok Junior High School is $0.0054 \mathrm{ppm}$ and still below the maximum value of $3 \mathrm{ppm}$ in accordance with government's regulations. The low concentration of total VOC in Junior High School Depok is due to the low VOC sources in the classroom; based on the indoor observation there are only wooden chairs, wooden tables, whiteboard and markers, no arts and crafts activities. In addition, the research location is in urban areas. While in the previous studies, the total VOC source is higher in industrial than in urban and suburban areas. The factors affecting indoor pollutants are temperature in which during the measurement of total VOC, the classroom temperature is between $28.8{ }^{\circ} \mathrm{C}-31.9{ }^{\circ} \mathrm{C}$; it is in accordance with the VOC nature that is easy to evaporate.

One effect of indoor air pollution caused by exposure to $\mathrm{CO}_{2}$ and total $\mathrm{VOC}$ is pulmonary disorder. In this research, the lung function disorders $\mathrm{VEP}_{1} / \mathrm{KVP}$ experienced by junior high school students is $3.6 \%$. This result is the same as the Primary Health Care Survey of 2013 that the prevalence of Chronic Obstructive Pulmonary Disease (COPD) in Indonesia is 3.7\%, for prevalence of Chronic Obstructive Pulmonary Disease (COPD) in Depok is 3.5\%. Similar results occurs in the research in Argentina, the prevalence of lung function impairment based on $\mathrm{VEP}_{1} / \mathrm{KVP}$ 
criteria in urban area is 3.8\% (Wichmann et al., 2009).

There is no relationship found in this study between exposure of $\mathrm{CO}_{2}$ concentration and pulmonary disorders $\mathrm{VEP}_{1} / \mathrm{KVP}$ in Junior High School students. The study was the same as Sexton's, which stated that $\mathrm{CO}_{2}$ levels in rooms with a low concentration of $0.7 \%$ and $1.2 \%$ on four healthy individual could not be used to measure lung function, lung volume, gas mixing, and the difference is slightly changed in the function of the gas exchange unit but does not have a detrimental effect on health. Possible pathophysiological changing in lung function and structure with the concentration of $0.7 \%$ and $1.2 \%$ in a given period of time is considered low (Sexton, Mueller, Elliot, Gerjer, \& Strohl, 1998). So it was found that there was no relationship between $\mathrm{CO}_{2}$ and pulmonary disorders that the proportion of patients with pulmonary disorders was lacking in the amount and concentration of indoor $\mathrm{CO}_{2}$ was below the standard quality value.

VOCs are compounds that have a high impact on respiratory disorders, one of which can cause allergies and asthma (Mögel et al., 2011). The relationship of VOC exposures include xylene, ethylbenzene and toluene are related to asthma and asthma symptom, while the pulmonary disorders are related to the exposure of environmental endotoxin and indoor air exposure including tobacco smoke and volatile organic compounds (Shook-Sa et al., 2017).

The research in Italy was finds that children living in petrochemical industry areas indicate a relationship between VOC exposure and increasing respiratory illness (Cipolla et al., 2016; Wichmann et al., 2009). Research in Sardinia reports was teenagers from 12 - 14 years old living in petrochemical's contaminated area have a decreasing lung function and inflammation (Rusconi et al., 2011). This research is contrast to the previous studies since the result indicates no significant relationship between VOC concentration in the classroom and pulmonary disorders in the students ( $\mathrm{p}$ value $=0.374$ ). It may be due to the proportion of pulmonary disorders at a low level and the total concentration of VOC is still below the listed threshold.

The covariate variables analyzed were gender which showed no association with pulmonary disorders, this is different from the results of a study conducted in China which found that lung disorders in girls were more susceptible to ambient air pollutants compared to boys (Liu \& Zhang, 2009). However, it is in line with the study in Semarang which suggests that there is no relationship between sex and pulmonary disorders (Wulansari, 2016). The insignificant relationship might be caused by the approximate the same number of pulmonary disorders in each group.

There is no significant relationship between nutritional status and pulmonary disorders of $\mathrm{VEP}_{1} / \mathrm{KVP}$ in students. This result is similar to a study conducted in Colombo which found that students aged 9 - 15 years, $20 \%$ were obese in nutritional status and the average value of KVP, VEP1 and FEF was $25-75 \%$ lower in the abnormal weight group and there is no significant difference. Some mechanisms may be related to obesity to cause respiratory problems, such as asthma symptoms that correlate with mechanical effects and adipose tissue in the lungs, respiratory inflammation and hyper bronchial response (Liyanage et al., 2016). There is no relationship found in this study due to mostly of children have normal nutritional status that is $69.1 \%$.

A research in Spain states that the prevalence of respiratory symptoms is higher in smoker. VEP ${ }_{1}$ damage and $\mathrm{VEP}_{1} / \mathrm{KVP}$ ratios are directly related to the number of smoked cigarettes in the adults (Urrutia et al., 2005). Research in America on the children aged 10-18 years old urges that cigarette smoking is related to mild airway obstruction and slowing the development lung function in teenagers (Gold et al., 1996). However, this study found that there was no significant relationship between students' smoking habits and pulmonary disorders, this happened because there were only a few students who smoked and only one cigarette was consumed. The students who smoke are only curious about how it tastes. In this study, there were several students who smoked in the school environment, especially in the State Middle School, so there was a need for efforts from the school to supervise students through a smoking cessation campaign that could be held through school health activities.

Research in Brazil states that boys who engage in leisure time physical have higher VEP $/ \mathrm{KVP}$ and FEF than those who do not perform physical activity (da Silva et al., 2016). Whereas in China, girls who perform physical activities have higher lung function than children who are passive (Ji, Wang, Liu, \& He, 2013). This study is different from Silva and Ji but this study is the same as the study found in children 11 - 15 in Pelosia Brazil that VEP1 is not related to physical activity (Menezes et al., 2012). The number of students who have less physical activity is higher, so that students are expected to do more and secure physical activities. According to WHO states that physical activity can be carried out for 60 minutes every day with moderate to intensive sports such as walking, cycling, and other sports that are beneficial to health.

Student activity in the classroom results in higher concentration of pollutants. Therefore, ventilation is very 
important to maintain indoor air quality (Csobod et al., 2010). A research in two schools in Paris indicates that indoor air quality is better in a mechanically ventilated class than in a window ventilated class. The concentrations range from $750 \mathrm{ppm}-1.500 \mathrm{ppm}$ of $\mathrm{CO}_{2}$ in a window-ventilated classroom. The total concentration of VOC in the class is higher by $200-620 \mu \mathrm{g} / \mathrm{m}^{3}$ compared to the outdoor (Kelly, Maupetit, \& Robine, 2002). The result of this study is in contrast to the result of previous research.

The limitations of this study is in the design, that is cross-sectional, so it can only describe the problem in general and the measurement that was conducted once described the condition of exposure for a moment only.

\section{Conclusion}

The conclusion in this study was no effect of exposure to $\mathrm{CO}_{2}$ and $\mathrm{VOC}$ concentrations related to student lung disorders due to $\mathrm{CO}_{2}$ concentrations and total VOCs that were still below the threshold. however, efforts will be need to be made to improve clean and healthy behaviors in schools that must be carried out together with relevant agencies, improve class ventilation, and future research can be done to get deeper parameters in other indoor air pollutants with respiratory diseases or degenerative diseases.

\section{Acknowledgement}

The author gratefully acknowledges the Universitas of Indonesia for providing financial support for this research through Final Project Research Grant (Hibah Riset Penelitian Tugas Akhir) 2018, No. 2182/UN2.R3.1/HKP.05.00/2018 and generosity of various participants.

\section{Competing Interests Statement}

The authors declare that there are no competing or potential conflicts of interest.

\section{References}

ATSDR. (2003). Comparison of Exposure to Volatile Organic Compound Among Louisiana Recident. Health (San Francisco).

Bruce, N., Perez-Padilla, R., \& Albalak, R. (2000). Indoor air pollution in developing countries: a major environmental and public health challenge. Bulletin WHO, 78(9), 1078-1092.

Budiyono, A. (2001). Pencemaran Udara : Dampak Pencemaran Udara Pada Lingkungan. Dirgantara, 2(1), 21-27.

Cakmak, S., Dales, R. E., Liu, L., Kauri, L. M., Lemieux, C. L., Hebbern, C., \& Zhu, J. (2014). Residential exposure to volatile organic compounds and lung function: Results from a population-based cross-sectional survey. Environmental Pollution, 194, 145-151. https://doi.org/10.1016/j.envpol.2014.07.020

Cicolella, A. (2008). Les composés organiques volatils (COV): Définition, classification et propriétés. Revue Des Maladies Respiratoires, 25(2), 155-163. https://doi.org/10.1016/S0761-8425(08)71513-4

Cipolla, M., Bruzzone, M., Stagnaro, E., Ceppi, M., Izzotti, A., Culotta, C., \& Piccardo, M. T. (2016). Health Issues of Primary School Students Residing in Proximity of an Oil Terminal with Environmental Exposure to Volatile Organic Compounds. BioMed Research International, 2016. https://doi.org/10.1155/2016/4574138

Csobod, E., Rudnai, P., \& Vaskovi, E. (2010). School Environment and Respiratory Health of Children ( SEARCH). Szentendre: The Regional Enviromental Center For Central and Eastrn Europe.

da Silva, B. G. C., Wehrmeister, F. C., Quanjer, P. H., Pérez-Padilla, R., Gonçalves, H., Horta, B. L., ... Menezes, A. M. B. (2016). Physical Activity in Early Adolescence and Pulmonary Function Gain From 15 to 18 Years of Age in a Birth Cohort in Brazil. Journal of Physical Activity and Health, 13(11), 1164-1173. https://doi.org/10.1123/jpah.2016-0056

Elliott, L., Longnecker, M. P., Kissling, G. E., \& London, S. J. (2006). Volatile organic compounds and pulmonary function in the Third National Health and Nutrition Examination Survey, 1988-1994. Environmental Health Perspectives, 114(8), 1210-1214. https://doi.org/10.1289/ehp.9019

EPA. (2011). Volatile Organic Compounds Emissions (Vol. 1990).

EPA. (2016). Overview of Greenhouse Gases Greenhouse Gas (GHG) Emissions US EPA.

Ferreira, A. M. da C., \& Cardoso, M. (2014). Indoor air quality and health in schools. Jornal Brasileiro de Pneumologia: Publicaçäo Oficial Da Sociedade Brasileira de Pneumologia E Tisilogia, 40(3), 259-68. https://doi.org/10.3760/cma.j.issn.0366-6999.2009.17.007

Gaihre, S., Semple, S., Miller, J., Fielding, S., \& Turner, S. (2014). Classroom Carbon Dioxide Concentration, School Attendance, and Educational Attainmen. Journal of tTheoretical Social Phycologiy, 84(9), 569-574. 
https://doi.org/10.1111/josh.12183.

Gaur, M., Singh, R., \& Shukla, A. (2016). Variability in the Levels of BTEX at a Pollution Hotspot in New Delhi, India. Journal of Environmental Protection, 7(10), 1245-1258. https://doi.org/10.4236/jep.2016.710110

Gold, D. R., Wang, X., Wypiy, D., Speizer, F. E., Ware, J. H., \& Dockery, D. W. (1996). Effect Of Cigarette Smoking on Lung Function In Adolescent Boys and Girls. The New England Journal of Medicine, 335(15), 931-937.

Greenwald, R., Sarnat, S. E., Raysoni, A. U., Li, W. W., Johnson, B. A., Stock, T. H., ... Sarnat, J. A. (2013). Associations between source-indicative pollution metrics and increases in pulmonary inflammation and reduced lung function in a panel of asthmatic children. Air Quality, Atmosphere and Health, 6(2), 487-499. https://doi.org/10.1007/s11869-012-0186-3

Hutter, H., Moshammer, H., Wallner, P., Hohenblum, P., Kociper, K., Piegler, K., \& Kundi, M. (2010). Indoor air pollutants in elementary schools in Austria : Is there an impact on the lung-function of schoolchildren ? In Conference Indoor Air Pollutant (pp. 10-13).

Ji, J., Wang, S., Liu, Y., \& He, Q. (2013). Physical Activity and Lung Function Growth in a Cohort of Chinese School Children: A Prospective Study. PLoS ONE, 8(6), e66098. https://doi.org/10.1371/journal.pone.0066098

Jia, C., Batterman, S., \& Godwin, C. (2008). VOCs in industrial, urban and suburban neighborhoods, Part 1: Indoor and outdoor concentrations, variation, and risk drivers. Atmospheric Environment, 42(9), 2083-2100.

Kelly, P. O., Maupetit, F., \& Robine, E. (2002). Indoor Air quality In Schools: The Impact Of Ventilation Conditions And Indoor Activities. In Proceeding : Indoor Air 2002 (pp. 109-114).

Liu, L., \& Zhang, J. (2009). Ambien air pollution in children lung china. Environment International, 35(1), 178-186. https://doi.org/10.1016/j.envint.2008.06.004

Liyanage, G., Jayamanne, B. D., Aaqiff, M., \& Sriwardhana, D. (2016). Effect of body mass index on pulmonary function in children. Ceylon Medical Journal, 61(4), 163. https://doi.org/10.4038/cmj.v61i4.8382

Madureira, J., Paciência, I., Rufo, J., Ramos, E., Barros, H., Teixeira, J. P., \& de Oliveira Fernandes, E. (2015). Indoor air quality in schools and its relationship with children's respiratory symptoms. Atmospheric Environment, 118(July), 145-156. https://doi.org/10.1016/j.atmosenv.2015.07.028

Mahyuddin, N., \& Awbi, H. B. (2012). A review of $\mathrm{CO} 2$ measurement procedures in ventilation research. International Journal of Ventilation, 10(4), 353-370. https://doi.org/10.1080/14733315.2012.11683961

Mangunnegoro, H., Suryatenggara, W., Yunus, F., Supandi, P. Z., Giriputro, S., Sutoyo, D. K., ... Hidayat, S. (1992). Nilai Normal Faal Paru Indonesia. Jakarta.

Martins, P. C., Viegas, J., Papoila, A. L., Aelenei, D., Caires, I., Araújo-Martins, ... Neuparth. (2014). CO2 concentration in day care centres is related to wheezing in attending children. Europan Jounal Pediactrict, 173(8), 1041-1049. https://doi.org/10.1007/s00431-014-2288-4

Marzocca, A., Di Gilio, A., Farella, G., Giua, R., \& de Gennaro, G. (2017). Indoor Air Quality Assessment and Study of Different VOC Contributions within a School in Taranto City, South of Italy. Environments, 4(1), 23. https://doi.org/10.3390/environments4010023

Menezes, A. M. B., Wehrmeister, F. C., Muniz, L. C., Perez-Padilla, R., Noal, R. B., Silva, M. C., ... Hallal, P. C. (2012). Physical activity and lung function in adolescents: The 1993 Pelotas (Brazil) birth cohort study. Journal of Adolescent Health, 51(SUPPL. 6), 27-31. https://doi.org/10.1016/j.jadohealth.2012.06.023

Mögel, I., Baumann, S., Böhme, A., Kohajda, T., Von Bergen, M., Simon, J. C., \& Lehmann, I. (2011). The aromatic volatile organic compounds toluene, benzene and styrene induce COX-2 and prostaglandins in human lung epithelial cells via oxidative stress and p38 MAPK activation. Toxicology, 289(1), 28-37. https://doi.org/10.1016/j.tox.2011.07.006

Raysoni, A. U., Stock, T. H., Sarnat, J. A., Chavez, M. C., Sarnat, S. E., Montoya, T., ... Li, W. W. (2017). Evaluation of VOC concentrations in indoor and outdoor microenvironments at near-road schools. Environmental Pollution, 231, 681-693. https://doi.org/10.1016/j.envpol.2017.08.065

Razali, N. Y. Y., Latif, M. T., Dominick, D., Mohamad, N., Sulaiman, F. R., \& Srithawirat, T. (2015). Concentration of Particulate Matter, $\mathrm{CO}$ and $\mathrm{CO} 2$ in Selected Schools in Malaysia. Building and Environment, 87, 108-116. https://doi.org//doi.org/10.1016/j.envint.2015.01.015 
Rusconi, F., Catelan, D., Acceta, G., Peluso, M., Pisteli, R., \& Barbone, F. (2011). Asthma Symptoms, Lung Function, and Markers of Oxidative Stress and Inflammation in Children Exposed to Oil Refinery Pollution. Journal Of Asthma, 48(1), 84-90. https://doi.org/10.3109/02770903.2010.538106

Salthammer, T., Uhde, E., Schripp, T., Schieweck, A., Morawska, L., Mazaheri, M., ... Kumar, P. (2016). Children's well-being at schools: Impact of climatic conditions and air pollution. Environment International, 94, 196-210. https://doi.org/10.1016/j.envint.2016.05.009

Samiaji, T. (2010). Sebaran Emisi Gas CO2 Di Indonesia. In Prosiding Penerbangan dan Antariksa (pp. 185-192). Serpong: Pusfatsatklim.

Samsoedin, I., Susidhamawan, I. W., Pratiwi, \& Wahyono, D. (2015). Peran Pohon dalam Menjaga Kualitas Udara di Perkotaan. (H. S. Arifin, H. Gunawan, \& M. Turjaman, Eds.). Jakarta: Forda Press.

Sexton, J., Mueller, K., Elliot, A., Gerjer, D., \& Strohl, K. (1998). Low level CO2 effects on pulmonary function in humans. Environment Medicine, 69(4), 387-389.

Shook-Sa, B. E., Chen, D.-G., \& Zhou, H. (2017). Using structural equation modeling to assess the links between tobacco smoke exposure, volatile organic compounds, and respiratory function for adolescents aged 6 to 18 in the United States. International Journal of Environmental Research and Public Health, 14(10). https://doi.org/10.3390/ijerph14101112

Supu, A., \& Jalaludin, J. (2017). Indoor Air Quality and Its Association With Respiratory Health Preschool Children in Shah Alam and Hulu Langat, Selangor. Malaysian Journal of Public Health, 1(May), 78-88.

Talarosha, B. (2016). Konsentrasi $\mathrm{CO}_{2}$ pada Ruang Kelas dengan Sistem Ventilasi Alami, sebuah Konsentrasi CO 2 pada Ruang Kelas dengan Sistem Ventilasi Alami, sebuah Penelitian Awal. In Prosiding Temu Ilmiah IPLBI (Vol. 2). https://doi.org/10.32315/jlbi.6.1.22

Urrutia, I., Capelastegui, A., Quintana, J. M., Muñiozguren, N., Basagana, X., Sunyer, J., ... Vega, A. (2005). Smoking habit, respiratory symptoms and lung function in young adults. European Journal of Public Health, 15(2), 160-165. https://doi.org/10.1093/eurpub/cki113

WHO. (2009). WHO Guidelines for Indoor Air Quality. WHO.

Wichmann, F. A., Müller, A., Busi, L. E., Cianni, N., Massolo, L., Schlink, U., ... Sly, P. D. (2009). Increased asthma and respiratory symptoms in children exposed to petrochemical pollution. Journal of Allergy and Clinical Immunology, 123(3), 632-638. https://doi.org/10.1016/j.jaci.2008.09.052

Wulansari, A. (2016). Kualitas udara ambien dan fungsi paru siswa sekolah dasar di Yogyakarta. BKM JOurnal of Community Medicine and Public Health, 32(3), 83-88.

\section{Copyrights}

Copyright for this article is retained by the author(s), with first publication rights granted to the journal.

This is an open-access article distributed under the terms and conditions of the Creative Commons Attribution license (http://creativecommons.org/licenses/by/4.0/). 